Natalia Kamińska, Anna Kledzik, Klaudia Nawrocka (Uniwersytet im. Adama Mickiewicza w Poznaniu)

\title{
Wzorce zawierania małżeństw w dziewiętnastowiecznym Poznaniu
}

\section{Wprowadzenie: Instytucja małżeństwa w dziewiętnastowiecznym Poznaniu}

W dziewiętnastowiecznym Poznaniu na mocy postanowień administracji pruskiej wszystkie małżeństwa zawierane były w kościele. Ówczesne prawo nie uznawało związków w konkubinacie. Ponieważ traktowane były one jako nielegalne, od 1822 r. całej rejencji poznańskiej administracja pruska nakłaniała obywateli do zalegalizowania nieformalnego związku ${ }^{1}$. Śluby zawierano przeważnie w parafii panny młodej. Bardzo istotną kwestią, poprzedzającą zawarcie związku małżeńskiego, były zapowiedzi, których wymóg ogłoszenia $\mathrm{z}$ odpowiednim wyprzedzeniem wynikał z przepisów prawa krajowego. Zapowiedzi miały służyć wykryciu ewentualnych przeszkód na drodze do zawarcia małżeństwa. Rejestracja zawieranych małżeństw odbywała się poprzez wpis do ksiąg metrykalnych, prowadzonych przez proboszczów parafii. Obowiązek wstępowania w związek małżeński wyłącznie poprzez ślub kościelny trwał do końca 1873 r. W 1874 r. powołano w zaborze pruskim urzędy stanu cywilnego. Od tego czasu śluby zawierano w pierwszej kolejności w urzędzie, przed urzędnikiem państwowym².

Małżeństwa kościelne zawierane były zazwyczaj przez osoby tego samego wyznania. Kościół rzymskokatolicki udzielał ewentualnej dyspensy od przeszkody, jaką było wyznanie partnera - inne niż katolickie. Wiązało się to jednak z pewnymi konsekwencjami. Nowożeńcy podpisywali np. zobowiązanie dotyczące wychowania potomstwa tylko i wyłącznie w wierze katolickiej. Liczba zawieranych małżeństw, w których jeden z partnerów był inne-

${ }^{1}$ M. Kędelski, Stosunki ludnościowe w latach 1815-1918, [w:] Dzieje Poznania, 1793-1918, t. 2, red. J. Topolski, L. Trzeciakowski, Warszawa-Poznań 1994, s. 222-270.

2 Tamże. 
go wyznania, była w kościele rzymskokatolickim niewielka i nie przekraczała kilku procent. Dodatkową przeszkodą w poślubianiu partnera innej religii były koszty, jakie pociągało za sobą ubieganie się o zwolnienie z rygorystycznych przepisów, regulujących zawieranie ślubu. Powodowało to, iż o dyspensę ubiegali się najczęściej zamożniejsi mieszkańcy prowincji poznańskiej³

\section{Cel opracowania}

Wzorce zawierania małżeństw wiążą się z wieloma czynnikami, w tym m.in. z: religią, statusem społecznym, wielkością ośrodka zamieszkania partnerów. Celem niniejszej pracy jest charakterystyka wzorców zawierania małżeństw oraz ich różnorakich uwarunkowań w Poznaniu drugiej połowy XIX w.

\section{Materiały}

W niniejszej pracy wykorzystano urzędowe księgi małżeństw obwodu Piotrowo -losowo wybranego obwodu urzędu stanu cywilnego z Poznania. Jako cezurę badawczą przyjęto lata 1874-1899. Zebrany materiał obejmował zarejestrowane w tym czasie 491 ślubów. W utworzonej bazie danych znajdują się następujące informacje o partnerach: imię, nazwisko, data i miejsce urodzenia, data ślubu, miejsce zamieszkania, wykonywany przez nich zawód, stan cywilny, wyznanie oraz dane personalne rodziców. Warto podkreślić, iż dla potrzeb niniejszego opracowania wybrano księgi urzędowe, gdyż jedynie w tego typu rejestrach przyszli małżonkowie oraz świadkowie ślubu byli zobligowani do złożenia podpisu w księdze. $W$ księgach parafialnych, prowadzonych przez proboszczów parafii, nie było takiego wymogu.

W odniesieniu do XIX w. sposób składania podpisu stanowił niezbędny element umożliwiający stwierdzenie faktu posiadania (bądź też nieposiadania) wykształcenia. Ponieważ w niniejszej pracy analizowano m.in. wpływ wykształcenia na wiek $\mathrm{w}$ chwili ślubu, informacja o wykształceniu partnerów była niezbędna.

W księgach USC Piotrowo odnotowano trzy główne formy składnia podpisu, stanowiące dla nas podstawę oszacowania poziomu wykształcenia przyszłych małżonków. Analfabetyzm przejawiał się brakiem umiejętności złożenia podpisu w urzędowych dokumentach. Podpis złożony przez partnerów nieposiadających umiejętności pisania i czytania przyjmował zazwyczaj postać trzech krzyżyków. Partnerzy, którzy opanowali pisanie w podstawo-

\footnotetext{
${ }^{3}$ K. Makowski, Rodzina poznańska w I połowie XIX wieku, Poznań 1992.
} 
wym zakresie, a więc posiadali wyksztalcenie na poziomie bardzo podstawowym, pisali niezgrabne litery, podobne do tych, jakie stawiają osoby dopiero co uczące się pisać. Najlepiej wykształconych charakteryzował staranny, zamaszysty podpis.

W pracy wyróżniono trzy grupy partnerów wstępujących w związki małżeńskie, ze względu na ich umiejętność pisania: analfabetów, bardzo słabo wykształconych i dobrze wykształconych.

\section{Metody}

\subsection{Kombinacje par małżeńskich według stanu cywilnego partnerów. Wiek w chwili ślubu}

Na podstawie informacji o stanie cywilnym partnerów w chwili ślubu wydzielono następujące kategorie partnerów: kawalerowie, panny, wdowy, wdowcy. Obliczono parametry rozkładu wieku partnerów wstępujących w związek małżeński według ich stanu cywilnego oraz parametry rozkładu wieku w chwili ślubu dla par w następujących kombinacjach: kawaler-panna, kawaler-wdowa, wdowiec-panna, wdowiec-wdowa. Skupiono się na miarach położenia (średnia arytmetyczna, mediana) i rozproszenia (odchylenie standardowe). Określono również wartości maksymalne i minimalne wieku w chwili ślubu. Do obliczeń wykorzystano program STATISTICA ${ }^{4}$.

\subsection{Współczynniki korelacji}

W pracy policzono także współczynniki korelacji pomiędzy wiekiem partnerów w momencie ślubu, pomiędzy wykształceniem partnerów (określonym na podstawie sposobu złożenia podpisu w księdze małżeństw) oraz pomiędzy statusem społecznym partnerów (określonym na podstawie informacji o wykonywanym zawodzie).

\section{Wyniki i dyskusja}

\subsection{Kombinacje par małżeńskich}

Na terenie objętym przez USC Piotrowo w okresie od 1874 do $1899 \mathrm{r}$. przeważały małżeństwa zawarte po raz pierwszy, czyli pomiędzy kawalerami i pannami. $\mathrm{W}$ całym materiale stanowiły one przeszło 73 proc. wszyst-

\footnotetext{
${ }^{4}$ STATISTICA Version 11. StatSoft, Inc. URL: www.statsoft.com.
} 
kich małżeństw. Kolejną grupą, mniej licznie reprezentowaną, były związki kawalerów z wdowami oraz wdowców z pannami. Obie kombinacje stanowiły odpowiednio ponad 6 proc. i 5 proc. całości materiału. Najmniej liczne były związki wdów z wdowcami (3,5 proc.) (Ryc. 1$)$. Nasze wyniki nie odbiegają od uzyskanych dla innych populacji z historycznych ziem polskich. W luterańskiej parafii Trzebosz, zlokalizowanej na pograniczu Wielkopolski i Śląska, odsetek małżeństw pomiędzy kawalerami i pannami wynosił ponad 80 proc. Ponowne małżeństwa najczęściej były zawierane przez wdowców, którzy poślubiali panny, i stanowiły one w Trzeboszu około 10 proc., $\mathrm{w}$ dalszej kolejności pomiędzy wdowcami a wdowami (5,25 proc.), najrzadziej zaś pomiędzy wdowami wychodzącymi za mąż za kawalerów - te z kolei stanowiły zaledwie 2 proc. całości materiału ${ }^{5}$. Z badań związków małżeńskich ze względu na stan cywilny, przeprowadzonych w podrzeszowskich wsiach (Galicja, zabór austriacki), wynika, iż najliczniej w związki małżeńskie wstępowały panny z kawalerami. Związki te stanowiły ponad 60 proc. wszystkich udzielonych tam ślubów. Na kolejnych miejscach znalazły się małżeństwa wdowców z pannami (15-20 proc.) oraz kawalerów z wdowami (5-12 proc.). Podobnie jak w Poznaniu, również tam najmniej zanotowano małżeństw pomiędzy wdowami i wdowcami (6-9 proc.) ${ }^{6}$. Podobne proporcje kombinacji par małżeńskich ze względu na stan cywilny partnerów utrzymywały się w innych katolickich parafiach wiejskich: w śląskiej parafii Płużnica Wielka i w małopolskiej parafii Wielkie Drogi ${ }^{7}$, w wielkopolskich wsiach: Szczepanowo i Dziekanowice ${ }^{8}$.

Warto nadmienić, iż w całym Poznaniu w pierwszej połowie XIX w. odsetek małżeństw zawieranych przez panny i kawalerów oscylował pomiędzy 69 proc. i 77 proc. W przypadku małżeństw powtórnych, ich ilość utrzymywała się przez jakiś czas na poziomie 5 proc., a potem systematycznie spadała ${ }^{9}$. W latach 1876-1885 znacznie obniżyła się umieralność w Poznaniu, co przełożyło się bezpośrednio na zmniejszenie liczby zawieranych małżeństw przez wdowy i wdowców, za to wzrósł odsetek związków małżeńskich zawieranych przez panny i kawalerów ${ }^{10}$.

${ }^{5}$ G. Liczbińska, Marriage patterns among Lutherans from the Parish of Trzebosz in the second half of the 19th century and the beginning of the 20th century, "The History of the Family" 2012, 17(2), s. 236-255.

${ }^{6}$ S. Rejman, Ludność podmiejska Rzeszowa w latach 1784-1880. Studium demograficzno-historyczne, Rzeszów 2006.

${ }^{7}$ E.A. Puch, Dynamika biologiczna polskich społeczności wiejskich z różnych systemów ekologiczno-kulturowych w XVIII i XIX wieku, „Przegląd Antropologiczny” 1993, r. 56, nr 1-2, s. 5-35.

${ }^{8} \mathrm{M}$. Domżol, Ocena stanu puli genów na podstawie analizy odległości matżeńskich w populacjach wiejskich z mikroregionu Ostrowa Lednickiego na przetomie XIX i XX wieku, „Studia Lednickie” 2002, nr 6, s. 127-141.

${ }^{9}$ K. Makowski, dz. cyt.

${ }^{10}$ M. Kędelski, dz. cyt. 


\subsection{Wiek w chwili ślubu}

Na wiek poznaniaków w chwili ślubu wpływało bardzo wiele czynników. W pierwszej kolejności moment ten był odgórnie regulowany przez prawo pruskie, które określało dolne granice wieku panny i kawalera w momencie ślubu. W przypadku mężczyzn wiek ten wynosił 21 lat, wiek kobiet zaś 16 lat $^{11}$. W dalszej kolejności na wiek $\mathrm{w}$ chwili ślubu miały wpływ tradycje i zwyczaje, które zakazywały kobietom wychodzenia za mąż poniżej dwudziestego roku życia ${ }^{12}$, a także wyznanie, które - jak w przypadku Żydów nakazywało wstępowanie w związek małżeński dopiero po 24 . roku życia ${ }^{13}$.

Zazwyczaj wiek mężczyzn w chwili zaślubin był zdecydowanie wyższy od normowanego prawnie, co mogło być związane z obowiązkiem wcześniejszego odbycia przez nich służby wojskowej ${ }^{14}$. Mężczyźni bardzo rzadko żenili się $\mathrm{w}$ wieku poniżej dwudziestu lat, najczęściej pomiędzy 25.-29. rokiem życia. W poznańskim obwodzie Piotrowo w latach 1874-1899 średni wiek kawalerów wynosił 25,8 lat, natomiast wiek panien był prawie o trzy lata niższy niż wiek kawalerów (Tab. 1.). W katolickiej wiejskiej parafii Bejsce średni wiek, w którym kawalerowie żenili się po raz pierwszy wynosił na początku XIX w. niewiele ponad 27 lat, pod koniec XIX zaś był niższy o rok. Panny z Bejsc, wychodząc za mąż, miały średnio ok. 24 lat, czyli podobnie jak te z poznańskiego obwodu Piotrowo, a pod koniec XIX w. nawet 22 lata $^{15}$. W ewangelickiej parafii Trzebosz kawalerowie żenili się średnio w wieku 27 lat, z kolei panny miały $\mathrm{w}$ chwili ślubu średnio 25 lat $^{16}$. W Poznaniu $\mathrm{w}$ pierwszej połowie XIX w. aż 10 proc. kobiet wstępowało w związki małżeńskie w wieku od piętnastego do dziewiętnastego roku życia. W późniejszym czasie odsetek tak młodych panien obniżył się i w latach osiemdziesiątych i dziewięćdziesiątych XIX w. wynosił już zaledwie 4,5 proc. ${ }^{17}$ Wówczas też kobiety najczęściej wychodziły za mąż pomiędzy 25 . a 29. rokiem życia ${ }^{18}$.

${ }^{11}$ G. Liczbińska, Lutherans in the Poznań province. Biological dynamics of the Lutheran population from the 19th century and early 20th centuries, Hamburg 2015.

12 K. Makowski, dz. cyt.

${ }^{13}$ M. Kędelski, dz. cyt.

${ }^{14}$ G. Liczbińska, Die Beteiligung von Frauen und Männern lutherischen Glaubens an der Schaffung des Heiratsmusters im Regierungsbezirk Posen in der zweiten Hälfte des 19. Jahrhunderts, [w:] Zwischen Geschlecht und Nation Interdependenzen und Interaktionen in der multiethnischen Gesellschaft Polens im 19. und 20. Jahrhundert, red. M. Barelkowski, C. Kraft, I. Röskau-Rydel, s. 153$-167$.

${ }^{15}$ E. Piasecki, Ludność parafii bejskiej (woj. kieleckie) w świetle ksiag metrykalnych z XVIII-XX w., Warszawa 1990.

${ }^{16}$ G. Liczbińska, Marriage patterrns.

17 M. Kędelski, dz. cyt.

18 Tamże. 
Inaczej rzecz się miała w przypadku wdów i wdowców. Prawo pruskie nakazywało, aby wdowy mogły ponownie wyjść za mąż po upływie dziewięciu miesięcy od momentu ustania poprzedniego małżeństwa, wdowcy zaś sześć tygodni od ustania poprzedniego związku ${ }^{19}$. W poznańskiej dzielnicy Piotrowo wdowy wychodziły ponownie za mąż w wieku 33 lat, a wdowcy żenili się ponownie dziesięć lat później (Tab. 1.). W parafii bejskiej wiek wdów opiewał średnio na ok. 34 lata, wdowców zaś na 38 lat ${ }^{20}$; w parafii Trzebosz wynosił on 37 lat i 43 lata, odpowiednio dla wdów i wdowców ${ }^{21}$.

W obwodzie Piotrowo panny wychodzące za mąż za kawalerów miały średnio prawie 23 lata, a te wychodzące za mąż za wdowców były o ponad cztery lata starsze. Kawalerowie żenili się z pannami $\mathrm{w}$ wieku średnio 25,5 lat, natomiast $\mathrm{z}$ wdowami $\mathrm{w}$ wieku nieco ponad 27 lat. Wdowcy żeniący się z pannami mieli średnio 38 lat i byli młodsi od tych z wiążącymi się z wdowami o ponad dziesięć lat. Wdowy wychodzące za mąż za kawalerów były średnio aż o trzynaście lat młodsze od tych poślubiających wdowców, i liczyły w chwili ślubu nieco ponad 27 lat (Tab. 2.).

\subsection{Czynniki wpływające na wybór partnera}

Z tabeli 3. wynika, iż w poznańskim obwodzie USC Piotrowo statystycznie istotny był związek pomiędzy wiekiem kawalerów i panien, co oznacza, iż wiek był kryterium dobierania się partnerów. Literatura potwierdza to zjawisko $\mathrm{w}$ odniesieniu do innych populacji z historycznej Polski ${ }^{22}$. Tabela 4. przedstawia wartości współczynnika korelacji rang Spearmana dla wykształcenia partnerów wstępujących w związki małżeńskie po raz pierwszy, mierzonego - przypomnijmy - umiejętnością pisania. Zależność ta okazała się statystycznie istotna. Podobnie statystycznie istotny związek odnotowano pomiędzy pochodzeniem społecznym partnerów wstępujących w związek małżeński po raz pierwszy, ocenianym na podstawie wykonywanego przez nich zawodu (Tab. 5.). Z powyższych analiz wynika, iż w obwodzie Piotrowo o doborze partnerów wstępujących w związek małżeński po raz pierwszy decydował ich wiek, wykształcenie i pozycja społeczna.

Badania pokazują, iż bardzo duże znaczenie w doborze współmałżonka miało pochodzenie społeczne i idące za nim w parze wykształcenie ${ }^{23}$.

${ }^{19}$ K. Makowski, dz. cyt.

${ }^{20}$ E. Piasecki, dz. cyt.

${ }^{21}$ G. Liczbińska, Marriage patterrns.

22 Np.: M. Domżol, dz. cyt., G. Liczbinska, Lutherans in the Poznań province; E. Piasecki, dz. cyt.; E.A. Puch, dz. cyt.; A. Warach, Wiek zawierania małżeństw wśród ubogich i zamożnych katolików z XIX-wiecznego Poznania, „Poznański Rocznik Archiwalno-Historyczny” 2013, r. XVI, s. 111-124.

${ }^{23}$ Np. K. Makowski, dz. cyt.; S. Rejman, dz. cyt. 
Najlepiej wykształceni poznaniacy: inteligencja i właściciele ziemscy, najczęściej wybierali żony z własnego środowiska. Poślubiali córki wysokich oficerów i funkcjonariuszy, reprezentantów wolnych zawodów, rzemieślników, kupców, a także niższych urzędników. We własnej grupie zawodowej żony znajdywali najczęściej wysoko postawieni funkcjonariusze i oficerowie, a także przedstawiciele tzw. wolnych zawodów. Zdarzało się jednak, iż ci ostatni brali za żony dziewczęta pochodzące z niższych warstw społecznych: córki kupców i drobnych właścicieli ziemskich. Kobiety poprzez taki ślub zyskiwały zwykle prestiż, natomiast mężczyźni często bogacili się na posagu przyszłej żony. Kupcy i posiadacze dóbr szukali często partnerki w środowisku rzemieślniczym, ponieważ pomiędzy tymi dwiema grupami nie było zbyt dużych różnic społecznych. Ta sama sytuacja dotyczyła tzw. „zawodów umysłowych" 24 , których przedstawiciele żenili się z kobietami z rodzin rzemieślniczych. Oczywiście, zdarzały się sytuacje, w których rzemieślnicy czy posiadacze ziemscy poślubiali córki służących, wyrobników i chłopów ${ }^{25}$. W Poznaniu najbardziej zamkniętą grupą zawodową byli rzemieślnicy. W przeważającej większości wybierali oni żony z tej samej grupy społecznej, gdyż głównie chodziło o to, aby połączyć swój warsztat z warsztatem ojca panny młodej. Jednak obniżający się poziom życia rzemieślników, zwłaszcza w pierwszej połowie XIX w., spowodowal, iż musieli oni szukać żon także w niższych grupach społecznych. Często zaś poślubiali służące oraz córki chłopów bądź czeladników. Córki chłopów i chałupników wychodziły za mąż za czeladników, służących lub robotników ${ }^{26}$.

\section{Podsumowanie}

W poznańskim obwodzie Piotrowo, podobnie jak w innych populacjach historycznej Polski, największy odsetek zawieranych małżeństw stanowiły śluby panien z kawalerami, a najniższy wdowców z wdowami.

W USC Piotrowo średni wiek panien w chwili ślubu wynosił nieco ponad 23 lata, kawalerów zaś 26 lat.

W obwodzie Piotrowo istotnym kryterium doboru partnerów był ich wiek, pochodzenie społeczne oraz wykształcenie.

\footnotetext{
${ }^{24}$ K. Makowski, dz. cyt.

25 Tamże.

${ }^{26}$ Tamże.
} 


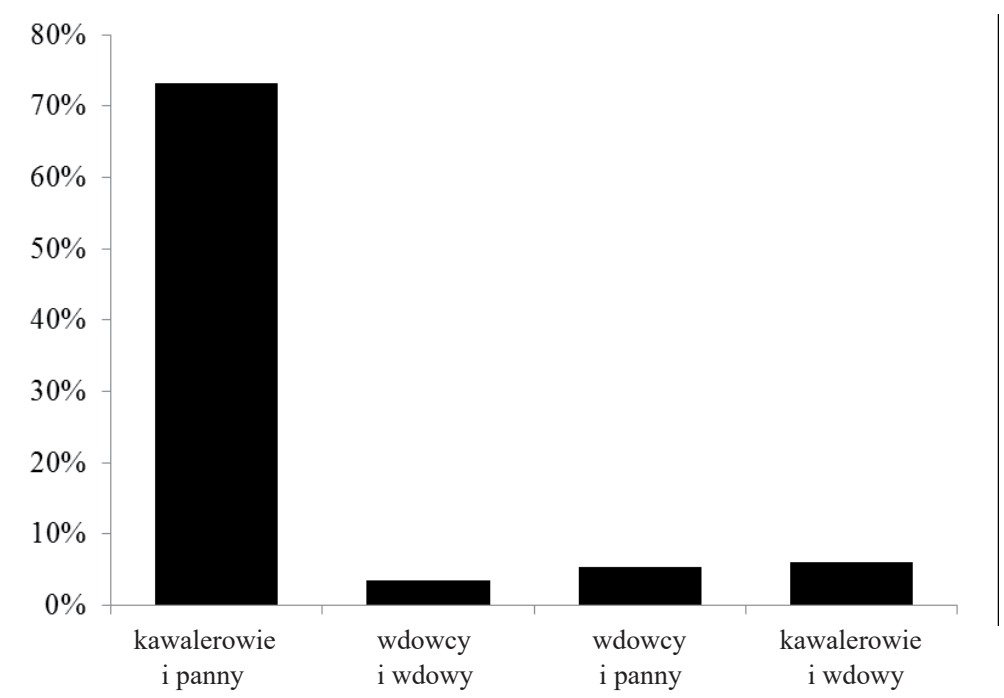

Ryc. 1. Kombinacje par według stanu cywilnego partnerów w poznańskiej dzielnicy Piotrowo, 1874-1899

Tab.1. Wiek partnerów w momencie zawarcia związku małżeńskiego w poznańskiej dzielnicy Piotrowo, 1874-1899

\begin{tabular}{|l|r|r|r|r|r|r|}
\hline \multicolumn{1}{|c|}{ Stan cywilny } & \multicolumn{1}{c|}{ N } & Średnia & Me & \multicolumn{1}{c|}{ SD } & Min & Max \\
\hline Panna & 406 & 23,05 & 22 & 4,77 & 16 & 55 \\
Wdowa & 53 & 33,36 & 35 & 11,57 & 19 & 76 \\
Kawaler & 400 & 25,79 & 25 & 4,07 & 17 & 45 \\
Wdowiec & 49 & 43,35 & 41 & 11,77 & 25 & 72 \\
\hline
\end{tabular}

Tab. 2. Wiek w chwili ślubu w kombinacjach par w poznańskiej dzielnicy Piotrowo, 1874-1899

\begin{tabular}{|c|c|c|c|c|c|c|}
\hline \multicolumn{1}{|c|}{ Stan cywilny } & $\mathrm{N}$ & Średnia & $\mathrm{Me}$ & $\mathrm{SD}$ & Min & Max \\
\hline Kawaler-panna & \multirow{2}{*}{360} & 25,56 & 25,0 & 3,68 & 17 & 45 \\
& & 22,72 & 22,0 & 4,07 & 16 & 45 \\
\hline \multirow{2}{*}{ Kawaler-wdowa } & \multirow{2}{*}{30} & 27,30 & 26,0 & 5,71 & 20 & 41 \\
& & 27,33 & 24,5 & 7,35 & 19 & 43 \\
\hline \multirow{2}{*}{ Wdowiec-panna } & \multirow{2}{*}{26} & 38,27 & 39,0 & 7,45 & 25 & 54 \\
& & 26,04 & 24,0 & 7,60 & 18 & 46 \\
\hline \multirow{2}{*}{ Wdowiec-wdowa } & \multirow{2}{*}{17} & 47,18 & 44,0 & 13,66 & 25 & 72 \\
& & 40,59 & 41,0 & 13,62 & 19 & 76 \\
\hline
\end{tabular}


Tab. 3. Korelacja wieku w chwili ślubu w poznańskiej dzielnicy Piotrowo, 1874-1899

\begin{tabular}{|l|c|c|}
\hline Kategorie partnerów & $\mathrm{N}$ & Współczynnik korelacji \\
\hline Kawaler-panna & 360 & $\mathbf{0 , 1 4 2 *}$ \\
\hline
\end{tabular}

*wartość statystycznie istotna

Tab. 4. Współczynniki korelacji wykształcenia parterów w poznańskiej dzielnicy Piotrowo, 1874-1899

\begin{tabular}{|l|c|c|}
\hline Kategorie partnerów & $\mathrm{N}$ & Współczynnik korelacji \\
\hline Kawaler-panna & 491 & $\mathbf{0 , 4 8 4}^{*}$ \\
\hline
\end{tabular}

*wartość statystycznie istotna

Tab. 5. Współczynniki korelacji pochodzenia społecznego partnerów w poznańskiej dzielnicy Piotrowo, 1874-1899

\begin{tabular}{|l|c|c|}
\hline Kategorie partnerów & $\mathrm{N}$ & Współczynnik korelacji \\
\hline Kawaler-panna & 491 & $\mathbf{0 . 3 5 2}^{*}$ \\
\hline
\end{tabular}

*wartość statystycznie istotna

Natalia Kamińska, Anna Kledzik, Klaudia Nawrocka

\section{Wzorce zawierania małżeństw w dziewiętnastowiecznym Poznaniu}

\section{Streszczenie}

Celem pracy była charakterystyka wzorców zawierania małżeństw oraz ich różnorakich uwarunkowań w Poznaniu drugiej połowy XIX w. Wykorzystano urzędowe księgi małżeństw obwodu Piotrowo za lata 1874-1899. Na terenie objętym przez USC Piotrowo przeważały małżeństwa zawarte po raz pierwszy, czyli pomiędzy kawalerami i pannami. Stanowiły one przeszło 73 proc. wszystkich małżeństw. Kolejną grupą były związki kawalerów z wdowami oraz wdowców z pannami: odpowiednio ponad 6 proc. i 5 proc. całości materiału. W USC Piotrowo panny wychodzące za mąż za kawalerów miały średnio prawie 23 lata, zaś za wdowców były o ponad cztery lata starsze. Kawalerowie żenili się z pannami w wieku średnio 25,5 lat, natomiast $\mathrm{z}$ wdowami $\mathrm{w}$ wieku nieco ponad 27 lat. Wdowcy żeniący się z pannami mieli średnio 38 lat zaś ci wiążący się z wdowami o ponad dziesięć lat więcej. Wdowy wychodzące za mąż za kawalerów liczyły w chwili ślubu nieco ponad 27 lat. W poznańskim obwodzie Piotrowo o doborze partnerów wstępujących w związek małżeński decydował ich wiek, wykształcenie i pozycja społeczna. 


\title{
The patterns of concluding marriages in Poznan in the $19^{\text {th }}$ century
}

\begin{abstract}
The aim of the paper is to describe patterns of concluding marriages and various factors affecting them in Poznań in the second half of the 19th century. In order to do so, registrar's marriage books from the Piotrowo district for the years 1874-1899 were used. In the area covered by the Piotrowo Registrar Office, first marriages dominated, i.e. ones concluded between bachelors and maidens. They comprised over $73 \%$ of all marriages concluded. Another group were marriages between bachelors and widows and widowers and maidens - $6 \%$ and $5 \%$ of all marriages, respectively. In the Piotrowo Registrar Office, on the day of marriage, maidens marrying bachelors were 23 years old on average, while those marrying widowers were 27 . Bachelors married maidens at the age of 25.5 on average, while those who married widows were slightly above 27 . Widowers who married maidens were on average 38 years old, while those marrying widows -48 . Widows who married bachelors were slightly above 27 years old on the day of marriage. In the Piotrowo district of Poznan, the factors that influenced the choice of the spouse included age, education and social position.
\end{abstract}

